\title{
CONSPECIFIC POLLEN ON INSECTS VISITING FEMALE FLOWERS ON THE OAK PARASITE PHORADENDRON CORYAE (VISCACEAE)
}

\author{
William D. Wiesenborn ${ }^{1}$
}

\begin{abstract}
Phoradendron coryae (Viscaceae) is a dioecious, parasitic plant on oak trees and shrubs in Quercus (Fagaceae), and it occurs from Arizona to Texas and into northern Mexico. The species produces minute spherical flowers during summer. Dioecious flowering requires pollinating insects to carry pollen from male to female plants. I investigated the pollination of $P$. coryae parasitizing Quercus turbinella shrubs at 3 sites at different elevations in the Cerbat Mountains of northwestern Arizona during August-September 2015. I examined pollen from male flowers, aspirated insects landing on female flowers, and counted conspecific pollen grains carried by insects. The tricolpate pollen of $P$. coryae was semiangular to subangular in polar view and circular to depressed oval in equatorial view. Female flowers were visited by 2 species of Coleoptera in 2 families, 6 species of Diptera in 6 genera and 3 families, and 1 species of Hymenoptera. Insects on flowers were extremely small (most $<3 \mathrm{~mm}$ in length), and nearly all (99\%) of the pollen carried by insects was from $P$. coryae. Conspecific pollen was found on $67 \%$ of the insects identified. Pollen loads were low, with only $25 \%$ of the insects carrying $\geq 5$ grains. The beetle Attalus futilis (Melyridae) was the most frequently aspirated species, comprising $71 \%$ of the insects collected and occurring at all 3 sites. Most A. futilis (64\%) carried P. coryae pollen. The second most frequently collected insects were 2 species of Hippelates and Liohippelates flies (Chloropidae). The Liohippelates carried the most $P$. coryae pollen. Other insects with pollen included 2 additional species of Chloropidae, 2 species of flies in Tachinidae and Tephritidae, a species of beetle in Chrysomelidae, and a species of parasitic wasp in Figitidae. Phoradendron coryae appeared to be pollinated mostly by A. futilis beetles due to their apparent abundance and by Liohippelates flies due to their relatively high pollen loads.
\end{abstract}

Resumen.-Phoradendron coryae (Viscaceae) es una planta dioica y parásita de robles y arbustos de Quercus (Fagaceae), que se distribuye desde Arizona a Texas y en el norte de México. La especie produce flores diminutas esféricas durante el verano. La floración dioica requiere la polinización de los insectos para llevar el polen desde las plantas macho hasta las plantas hembra. Investigué la polinización de P. coryae que parasita arbustos Quercus turbinella en 3 áreas a distintas alturas en las montañas Cerbat, en el noroeste de Arizona, durante agosto y septiembre del 2015. Examiné el polen de las flores macho, insectos aspirados que se posaron en flores hembra y contabilicé los granos de polen conspecífico transportados por los insectos. El polen tricolpado de P. coryae era de semi-angular a sub-angular, desde el punto de vista polar, y de circular a ligeramente ovalado, bajo vista ecuatorial. Las flores hembra fueron visitadas por 2 especies de coleópteros de 2 familias, 6 especies de dípteros de 6 géneros y 3 familias, y 1 especie de himenópteros. Los insectos en las flores fueron extremadamente pequeños (la mayoría $<3 \mathrm{~mm}$ de longitud), y casi todo el polen transportado (99\%) por insectos fueron P. coryae. El polen conespecífico se encontró en el $67 \%$ de los insectos identificados. Las cargas de polen fueron bajas, con tan sólo el $25 \%$ de los insectos transportando $\geq 5$ granos. Los escarabajos Attalus futilis (Melyridae) fue la especie más frecuentemente succionada, comprendiendo el 71\% de los insectos colectados y presentes en los tres sitios. La mayoría de A. futilis $(64 \%)$ transportaron polen de P. coryae. Los segundos insectos colectados con mayor frecuencia fueron 2 especies de moscas Hippelates y Liohippelates (Chloropidae). La mayor parte del polen transportado por la Liohippelates fue de P. coryae. Otros insectos con polen incluyeron 2 especies adicionales de Chloropidae, 2 especies de moscas Tachinidae y Tephritidae, una especie de escarabajo Chrysomelidae, y una especie de avispa parásita Figitidae. Phoradendron coryae pareció ser polinizado principalmente por escarabajos A. futilis debido a su aparente abundancia, y por moscas Liohippelates debido a sus cargas relativamente altas de polen.

Phoradendron (Viscaceae), or mistletoe, is a genus of perennial plants that parasitize a wide variety of woody plants (Trelease 1916, Wiens 1964, Kuijt 2003). The genus includes 234 species distributed from the northern United States to northern Argentina and from eastern Pacific Islands to the eastern Caribbean (Kuijt 2003). Phoradendron plants obtain water and other inorganic nutrients from their host plants by tapping into xylem with their haustoria, and they produce organic nutrients from photosynthesis in leaves and stems (Kuijt 1969, 2003).

Flowers on Phoradendron (Kuijt 2003) are unisexual and typically around $1 \mathrm{~mm}$ in diameter. Male flowers are spherical, with a

1E-mail: wwiesenborn@fastmail.fm 
cavity enclosed by 3 or 4 petals that each supports a minute sessile anther. Female flowers are similar but contain a short style with an indistinct rounded or faintly bilobed stigma atop an inferior ovary. Both sexes of Phoradendron flowers contain a small vestigial nectar gland, described by Trelease (1916) as "apparently adapted to pollination by such short-tongued insects as flies and small bees." Phoradendron fruits are eaten by birds that disperse plants by defecating seeds (Kuijt 2003).

Dioecious flowering in many Phoradendron species makes it possible to study pollination by examining conspecific pollen loads on insects visiting flowers on female plants. This approach was used to examine pollination of Phoradendron californicum Nuttall (Wiesenborn 2016), a species found on trees and shrubs of Fabaceae in southwestern deserts. I found 13 species of flies in Diptera and 3 species of bees and wasps in Hymenoptera carrying $P$. californicum pollen to female flowers. Fruit flies in Tephritidae and blow flies in Calliphoridae appeared most likely to pollinate the species due to their high abundances on flowers or large loads of conspecific pollen.

Phoradendron coryae Trelease is a dioecious species of mistletoe found mostly on oaks, or Quercus (Fagaceae). It is the only mistletoe on Quercus in Arizona (Kearney and Peebles 1951). The systematics of the species is unsettled. Trelease (1916) first described P. coryae in his monograph of Phoradendron from plants examined on Quercus in Arizona, New Mexico, and northern Mexico. Kearney and Peebles (1951) also recognized the species in their flora and described it as nearly exclusive to various oak species and very common from Arizona to western Texas. Wiens (1964) reduced $P$. coryae to the rank of subspecies within Phoradendron villosum (Nuttall) Nuttall, also reflected in the flora by Munz (1974) and flora section by Hawksworth and Wiens (2002). In Kuijt's (2003) monograph of the genus, the subspecies was considered a synonym of Phoradendron serotinum ssp. tomentosum (Candolle) Kuijt. Despite these revisions, $P$. coryae retains acceptance (Allred and Ivey 2012) and is therefore used in the present study.

Phoradendron coryae is morphologically distinct from $P$. californicum in that it produces leaves, instead of scales, that are round to elliptic and up to $3 \mathrm{~cm}$ wide and $3.5 \mathrm{~cm}$ long (Trelease 1916). The species also differs from $P$. californicum in its near restriction to a single host genus within a different family, occurrence at higher elevations (1100-2600 m compared with $<1200 \mathrm{~m}$ in Arizona; Kearney and Peebles 1951), and more easterly distribution. Flowering seasons also differ between the 2 species, with $P$. coryae producing flowers during July-September (P. villosum in Munz 1974) instead of winter. Both species produce similar spherical flowers on spike-like inflorescences. Seeds of $P$. coryae and $P$. californicum may also be similarly dispersed by birds. Seeds of P. villosum are dispersed by a variety of fruit-eating birds in coastal California (Wilson et al. 2014).

I investigated pollination of $P$. coryae parasitizing Quercus turbinella E. Greene growing in different plant communities in northwest Arizona by examining pollen loads on insects visiting female flowers. I considered (1) what insect species carry $P$. coryae pollen to female flowers, (2) how specific these insects are to P. coryae flowers based on pollen loads, (3) whether there was any variation in amounts of P. coryae pollen carried by the individuals of these species, (4) which taxa of insects are more likely to pollinate $P$. coryae, and (5) whether the taxa of insects carrying pollen to female flowers are different between $P$. coryae and $P$. californicum.

\section{Methods}

The study was conducted in the Cerbat Mountains, $33 \mathrm{~km}$ northwest of Kingman, Mohave County, Arizona. I collected insects from $P$. coryae plants parasitizing $Q$. turbinella shrubs at 3 sites at different elevations along Big Wash Road, an unpaved road that ascends eastward from U.S. Highway 93. The only oaks growing at the sites were Q. turbinella, keyed to species with Kearney and Peebles (1951). The lowest site $\left(35.464^{\circ} \mathrm{N}, 114.202^{\circ} \mathrm{W}\right)$ was at an elevation of $1380 \mathrm{~m}$ within interior chaparral (Pase and Brown 1982) and supported mostly Q. turbinella, with scattered Pinus monophylla Torrey \& Frémont (Pinaceae), Juniperus osteosperma (Torrey) Little (Cupressaceae), Acacia greggii A. Gray (Fabaceae), Cercocarpus sp. (Rosaceae), and Gutierrezia sp. (Asteraceae). Cattle were present at the site in low density. The middle site $\left(35.465^{\circ} \mathrm{N}\right.$, 
$114.179^{\circ} \mathrm{W}$ ) was $2.1 \mathrm{~km}$ east at an elevation of $1620 \mathrm{~m}$, also within interior chaparral and predominated by $Q$. turbinella, with scattered P. monophylla, Cercocarpus sp., Gutierrezia sp., Nolina microcarpa S. Watson (Agavaceae), Arctostaphylos pringlei Parry (Ericaceae), and Garrya flavescens S. Watson (Garryaceae). The highest site $\left(35.452^{\circ} \mathrm{N}, 114.170^{\circ} \mathrm{W}\right)$ was $1.6 \mathrm{~km}$ southeast of the middle site at an elevation of $1864 \mathrm{~m}$ within Great Basin conifer woodland (Brown 1982). This site supported mostly P. monophylla followed by Q. turbinella, with scattered Cercocarpus sp., A. pringlei, and G. flavescens. Quercus turbinella flowers during spring (Nixon 1997), and the only plants seen in flower at the sites were herbaceous. The distribution of $P$. coryae and $Q$. turbinella extended $2.3 \mathrm{~km}$ west of the lowest site, down to an elevation of $1280 \mathrm{~m}$, along Big Wash Road. Phoradendron californicum occurred in the area but appeared to be parapatric with $P$. coryae. The closest $P$. californicum plant along Big Wash Road grew on an A. greggii shrub $0.6 \mathrm{~km}$ west of the furthest west $P$. coryae plant and at a lower elevation of $1248 \mathrm{~m}$. Maximum air temperatures averaged $13{ }^{\circ} \mathrm{C}$ in January and $37^{\circ} \mathrm{C}$ in July, and yearly precipitation (occurring mostly during December to March and July to September) averaged $262 \mathrm{~mm}$ during 1901-1967 at Kingman (DRI 2015). Rainfall (12 mm) occurred at the beginning of the study near the upper site at Packsaddle Mountain during 13-15 August 2015 (MCFCD 2015).

I collected insects from 2 female $P$. coryae plants (or clumps of plants) $0.5-1.0 \mathrm{~m}$ in diameter on different $Q$. turbinella host shrubs (1.5-3.0 $\mathrm{m}$ tall) at each site. I recognized female plants by the presence of fruit (Fig. la). Proximities of male $P$. coryae plants differed among the 6 female plants sampled: 3 female plants were next to a male plant on the same host, and 3 female plants were 1-2 $\mathrm{m}$ away from a male plant on the same host or on a different host. I collected insects at the lower site on 8 dates during 14 August-1 September 2015 , at the middle site on 8 dates during 16 August-1 September 2015, and at the upper site on 6 dates during 22-31 August 2015. Flowers on female and male plants (Fig. 1b, 1c) viewed with a hand lens were open during collections. Insects on female flowers were individually aspirated into a $125-\mathrm{mL}$ plastic screw-capped flask containing a 4-dram glass vial with $4 \mathrm{~mL}$ of $70 \% \mathrm{EtOH}$. Each insect was aspirated through a $13-\mathrm{cm}$-long tube with a 3-mm-diameter opening to the top of the flask where it dropped into the alcohol. Insects were aspirated from each plant for 15$100 \mathrm{~min}$ on each date, for a total $25.2 \mathrm{~h}$, during 06:10-10:50 Mountain Standard Time. Air temperature during collections was $25-36{ }^{\circ} \mathrm{C}$, relative humidity $21 \%-26 \%$, cloud cover $0 \%-95 \%$, and wind speed $<10 \mathrm{~km} \cdot \mathrm{h}^{-1}$. I deposited a pressing (UNLV 64429) of a host Q. turbinella shrub, a sampled $P$. coryae female plant, and a nearby male plant at the Wesley E. Niles Herbarium, University of Nevada, Las Vegas.

I examined pollen from $P$. coryae after mounting each sample in polyvinyl alcohol (Dafni 1992). I collected male inflorescences at the upper site into $70 \% \mathrm{EtOH}$ on 26 August 2015 and vortexed pollen from flowers. Alcohol containing pollen was centrifuged at 3400 revolutions $\cdot \mathrm{min}^{-1}$ for $5 \mathrm{~min}$, and the alcohol was drawn off and replaced with 3.5 $\mathrm{mL}$ of water. The water and suspended pollen was then poured into a $100-\mathrm{mL}$ teflon evaporating dish, and $1 \mathrm{~mL}$ of a $12 \%$ solution of hydrolyzed polyvinyl alcohol was added. The mixture was vortexed and dried $2 \mathrm{~h}$ at $55^{\circ} \mathrm{C}$. I viewed pollen grains embedded in the resulting clear-plastic film in brightfield microscopy, measured them with an eyepiece reticle at $40 \times$, photographed them through a $100 \times$ oil-immersion objective lowered onto the film, and described them following figure 11.3 in Faegri et al. (1989).

I also extracted, mounted, and examined pollen on insects aspirated from female flowers. Each collection vial was vortexed for $30 \mathrm{~s}$, and the alcohol and suspended pollen was centrifuged as described above. I drew off the alcohol, replaced it with $4 \mathrm{~mL}$ of water, centrifuged the pollen suspension a second time, drew off the water, and added $0.8 \mathrm{~mL}$ of water. I mixed the water and pollen, then transferred it with a pipette into a $35-\mathrm{mL}$ porcelain evaporating dish. I added $0.3 \mathrm{~mL}$ of the polyvinyl alcohol solution to the dish and vortexed and dried the mixture $1.5 \mathrm{~h}$ at $40{ }^{\circ} \mathrm{C}$. This process produced a circular film $25 \mathrm{~mm}$ in diameter containing pollen from each insect. Insects were mounted on points after drying in hexamethyldisilizane (HMDS) to prevent shrinkage (Brown 1993).

I examined the entire area of each circular film for pollen. I pressed the film between 2 


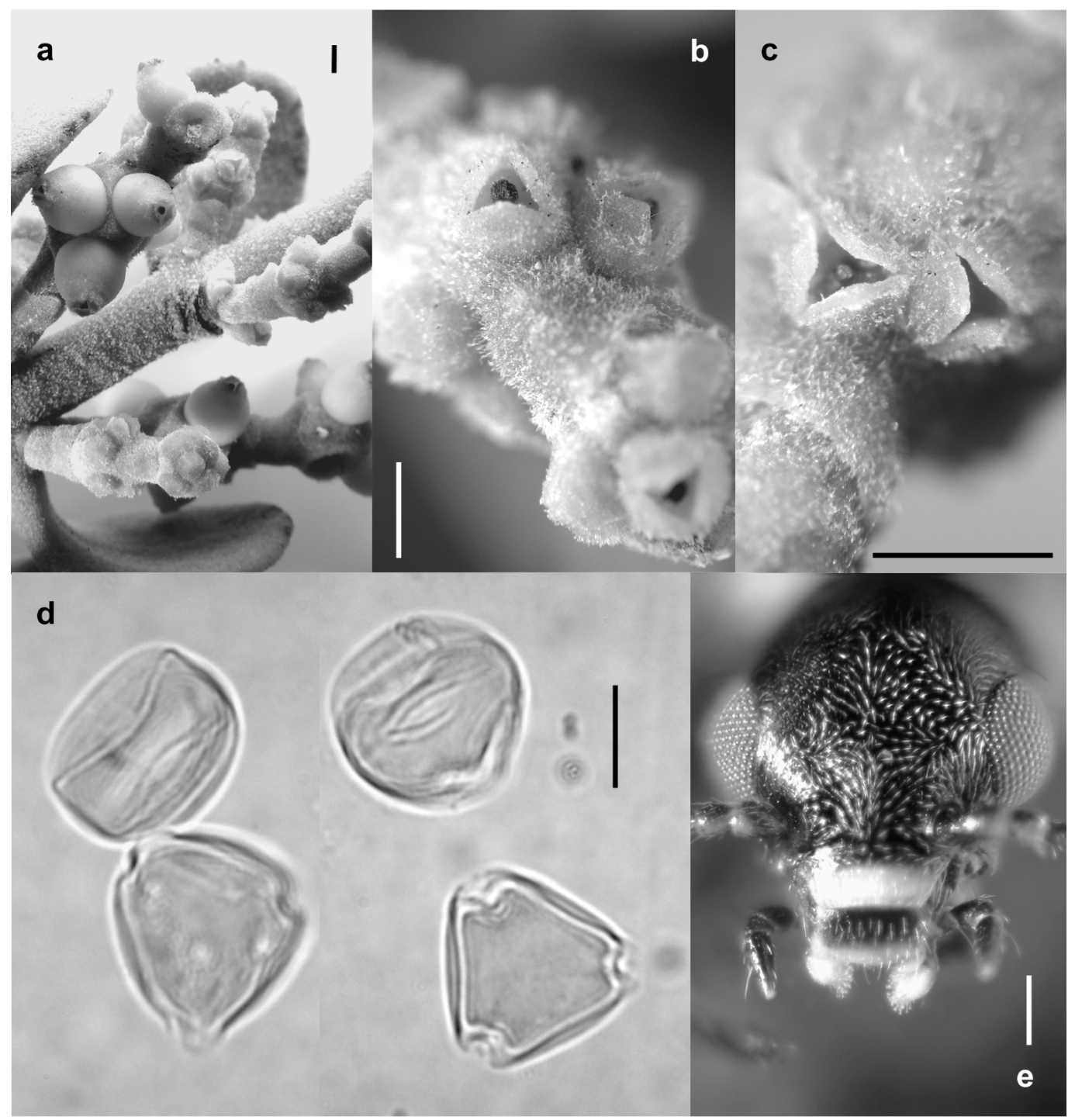

Fig. 1. Phoradendron coryae parasitizing Quercus turbinella in the Cerbat Mountains near Kingman, Arizona, during August 2015: a, stem with fruit and female flowers; b, female flowers; c, male flowers; $\mathbf{d}$, pollen from male flowers in equatorial view (upper grains) and polar view (lower grains); e, face of Attalus futilis melyrid beetle aspirated from a female flower showing white clypeus between upper frons and lower labrum and white paired maxillae with haired tips extended below labrum. Scale bars in panels a, b, and c are $1 \mathrm{~mm}$; scale bar in panel d is $10 \mu \mathrm{m}$; scale bar in panel e is $0.1 \mathrm{~mm}$.

microscope slides and scanned it at $100 \times$ with a compound microscope by moving the stacked slides with a mechanical stage. I recognized pollen grains by their yellow color and symmetrical shape, categorized grains as $P$. coryae or as differing from P. coryae, and counted grains in each category. I counted pollen as $P$. coryae unless it differed in size, shape, color, or exine sculpture. If I could not distinguish pollen as $P$. coryae at $100 \times$, I viewed it at $200 \times$.

I identified insects collected on $P$. coryae to the lowest taxonomic rank possible. I only identified insects with $>1$ specimen in a species. Coleoptera were keyed to family with Triplehorn and Johnson (2005). Melyridae were keyed to Malachiinae with Mayor (2002) and identified to species by matching specimens 
against those in the subfamily at the Entomology Research Museum, University of California, Riverside (UCRC). One specimen was photographed at different focal planes that were overlaid with CombineZP (Hadley 2013). Chrysomelidae were identified to genus by keying specimens with Riley et al. (2002) and comparing them with specimens at UCRC. Diptera were keyed to family with McAlpine (1981). Chloropidae were identified to genus by keying specimens with Sabrosky (1987) and comparing them with specimens at UCRC and at the Los Angeles County Museum of Natural History (LACM). Tachinidae were keyed to genus with Wood (1987) and to species with Reinhard (1942) and matched against specimens at UCRC and LACM. Tephritidae were keyed to species with Foote et al. (1993) and compared with specimens at UCRC. Hymenoptera were keyed to family and identified to subfamily with Triplehorn and Johnson (2005). An eyepiece reticle was used to measure lengths of insects, and vouchers were deposited at UCRC (ENT 460754-460767).

Amounts of $P$. coryae pollen carried by insects were compared among the predominant taxa collected. I used SYSTAT (version 10.2, Chicago, IL) to rank numbers of pollen grains on specimens and calculate the first quartile (containing the lower $25 \%$ of observations), median, and third quartile (containing the lower $75 \%$ of observations). Ranked pollen counts were compared among insect species with a one-way analysis of variance using GLM in SYSTAT. I decomposed the variation among species into independent contrasts (Neter et al. 1996) in GLM that compared pollen counts between Coleoptera and Diptera, between Chloropidae and other Diptera, and between the 2 most collected species in Chloropidae.

\section{RESUlTS}

Pollen grains from P. coryae were tricolpate but variable in shape. Grains in polar view varied from semiangular (rounded) in shape with intruding furrows (Fig. 1d, lower left) to subangular (flattened) with open furrows (Fig. ld, lower right). Grains in equatorial view were spherical but varied in shape from circular (Fig. 1d, upper right) to depressed oval with round sides and flat ends (Fig. 1d, upper left). Widths of furrows appeared to differ between the 2 shapes in equatorial view. Dimensions of pollen grains in equatorial view were also variable. Grains $(n=12)$ averaged $19 \mu \mathrm{m}$ (range 18-20 $\mu \mathrm{m}$ ) from corner to opposite side in polar view and $20(17-24) \mu \mathrm{m}$ long $\times 18(15-21) \mu \mathrm{m}$ wide in equatorial view. Pollen grains had smooth exines with 2 distinct layers apparent in polar view (Fig. 1d, lower right).

I aspirated and identified 146 insects from $P$. coryae female flowers: 2 species of Coleoptera in 2 families, 6 species of Diptera in 6 genera and 3 families, and 1 species of Hymenoptera (Fig. 2). The most abundant insect on female flowers was the flower beetle Attalus futilis Fall (Melyridae) (Fall 1917). This small beetle, around $2.4 \mathrm{~mm}$ in length, comprised $71 \%$ of the insects identified and was found at all 3 sites. Attalus females $(n=72)$ were more frequently aspirated than males $(n=31)$. A distinctive feature found on both sexes of A. futilis was the white clypeus that appeared as a band between the black frons and dark-brown labrum (Fig. 1e). The character needed to key A. futilis to genus in Mayor (2002), a distinct dorsal lobe on the second tarsal segment of the front legs of males (absent at UCRC), was variable and indistinct in this species. The lobe, weak but bearing 2 teeth, was visible on a leg that I removed (from a specimen kept in EtOH), treated with $\mathrm{NaOH}$, mounted on a slide, and examined with the compound microscope.

Flies in Chloropidae $(n=33)$, all in the subfamily Oscinellinae, were the second most abundant insects collected and included 4 species in different genera. Most (85\%) of the chloropids were keyed to Hippelates or to neotropical Lioscinella, now considered Liohippelates (Wheeler 2010). Specimens keyed to Lioscinella resembled Liohippelates at UCRC and LACM but possessed a short hind tibial spur instead of a long spur as seen on Hippelates. Liohippelates flies were distinctive by their shining black bodies and white eyes. All but one of the chloropids in Hippelates and Liohippelates were collected at the lower site, and except for 2 Liohippelates, the 2 genera occurred at the site on different plants. Other less common Chloropidae on flowers were keyed to Conioscinella and Olcella.

Other insects found on female flowers in low numbers included the flies Microchaetina valida Townsend (Tachinidae) and Neaspilota 


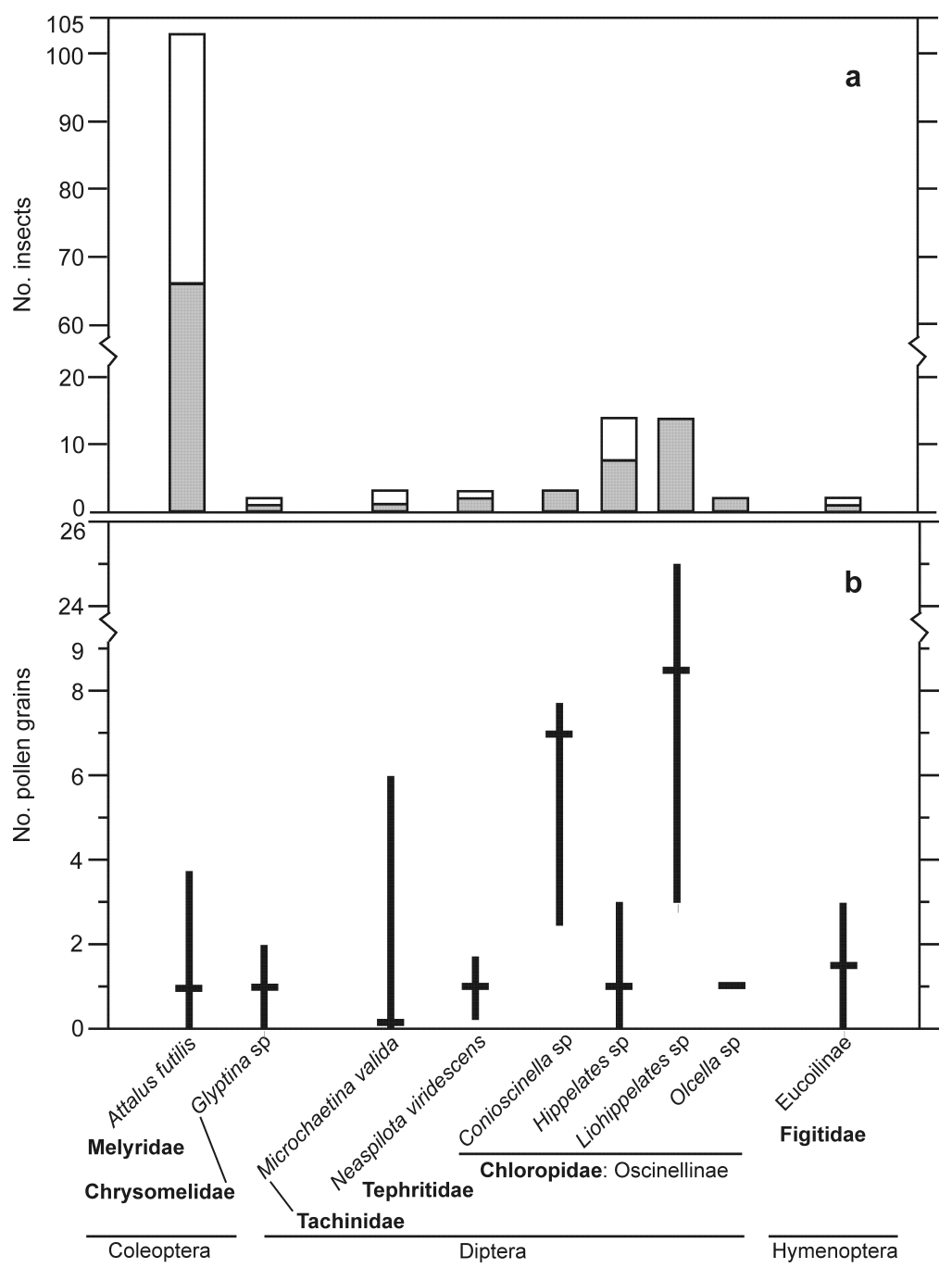

Fig. 2. Insects aspirated from female flowers on Phoradendron coryae parasitizing Quercus turbinella in the Cerbat Mountains near Kingman, Arizona, during 14 August-1 September 2015. Insect taxa are listed along the $x$-axis, with families in bold: a, numbers of aspirated insects with (closed bars) and without (open bars) P. coryae pollen in pollen load; $\mathbf{b}$, numbers of $P$. coryae pollen grains in pollen load on each insect. Horizontal bars are medians. Vertical bars connect the first and third quartiles (= pollen counts if $n=2)$.

viridescens Quisenberry (Tephritidae), the flea beetle Glyptina sp. (Chrysomelidae: Galerucinae: Alticini), and a parasitic wasp in Figitidae: Eucoilinae. Except for the tachinid fly, which was $5.0 \mathrm{~mm}$ in length, the insects identified on flowers were extremely small: A. futilis was the largest and the figitid wasp was the smallest at $1.4 \mathrm{~mm}$ in length.

Nearly all (99.2\%) of the pollen on insects aspirated from female flowers was identified as $P$. coryae. Only 9 pollen grains differing from the plant species were found on 5 insects, and most of these grains were distinguished by their darker brownish color or spiny sculpture. Phoradendron coryae pollen was found on $98(67 \%)$ of the insects collected and on all of the specimens in only 3 species (all chloropids) of the 9 species identified (Fig. 2). Only 37 insects $(25 \%)$ carried $\geq 5$ pollen grains, and 18 insects (12\%) carried $\geq 10$ grains. A Liohippelates fly in Chloropidae carried the most $P$. coryae pollen (265 grains).

Insects aspirated from $P$. coryae female flowers carried different amounts of conspecific 
pollen (Fig. 2). Amounts of $P$. coryae pollen on insects ( $n$; median, 1 st-3rd quartiles) did not differ $\left(F_{1,137}=0.88, P=0.35\right)$ between Coleoptera (105; 1.0, 3.0-3.3 grains) and Diptera (39; 2.0, 1.0-8.8 grains). Both beetles, the melyrid A. futilis and the chrysomelid Glyptina sp., carried low amounts of conspecific pollen. The total amount of pollen carried by the more abundant $A$. futilis was 422 grains. Ranked amounts of $P$. coryae pollen on A. futilis did not differ $(t=1.1, \mathrm{df}=101, P=$ $0.27)$ between males $(31 ; 1.0,0.0-2.0$ grains) and females ( $72 ; 1.0,0.0-4.0$ grains). Amounts of $P$. coryae pollen also did not differ $\left(F_{1,137}=\right.$ 2.46, $P=0.12$ ) between flies in Chloropidae (33; 3.0, 1.0-11 grains) and those in Tachinidae and Tephritidae $(6 ; 0.5,0.0-2.0$ grains). The 2 species of chloropids that were more frequently aspirated carried different amounts of pollen $\left(F_{1,137}=10.1, P=0.002\right)$, with the Liohippelates (14; 8.5, 3.0-25 grains) carrying more pollen than the Hippelates (14; 1.0, 0.0-3.0 grains). The species of Liohippelates carried a total of 452 grains. On the other less frequently collected chloropids, $P$. coryae pollen loads were high on the Conioscinella species and low on the Olcella species. Both species of Tachinidae and Tephritidae carried low amounts of pollen, with pollen loads being more variable in the tachinid. Only a few pollen grains were found on the species of parasitic wasps in Figitidae: Eucoilinae.

\section{Discussion}

Co-occurrence of the collected insect species and $P$. coryae flowers is dependent on the food and habitat requirements of larvae and adults. Although flower beetles in Melyridae do not have a well-known biology, those in Malachiinae are believed to be scavengers or predators as larvae, with adults also consuming pollen and nectar (Mayor 2002). Larvae of Collops georgianus Fall and Malachius ulkei Horn, which are also in Malachiini with Attalus, have been found in rocky soil beneath plants (King 1985) or underneath tree bark feeding on insect eggs (Dix 1990). Larvae of Collops have developed in the lab on honey and yeast (King 1985) and on mite and insect eggs, immature mites, insect pupae, and dead insect adults (Walker 1957). Attalus futilis is a widespread species that has been collected from California eastward to Colorado and Texas (Fall 1917, Marshall 1953, Tanner and Tanner 1974; UCRC specimens). The apparent abundance of A. futilis on P. coryae suggests its larvae may have developed on or near the plant or its host Q. turbinella. Beetles in Curculionidae and Bostrichidae, but not Melyridae, have been collected on Phoradendron tomentosum Engelmann in Texas (Whittaker 1984). In contrast, oak trees and shrubs can support a diverse coleopteran fauna: 150 species of beetles including a melyrid were collected from Quercus robur L. trees in Britain (Stork and Hammond 2013). Larvae of A. futilis may develop beneath oak bark similar to M. ulkei (Dix 1990) or in soil beneath oak trees or shrubs, similar to C. georgianus (King 1985).

Flies in Chloropidae also have varied larval diets. Larvae of most chloropids in Oscinellinae eat living or decomposing herbaceous plants, although they also consume immature insects, decomposing wood, and fungi (Nartshuk 2014). Adult chloropids in Hippelates and Liohippelates are commonly called eye gnats because of the propensity of many species to feed on secretions, especially at the eyes of humans and domestic animals. Flies at the lower site were landing in my eyes at the plant where Hippelates were aspirated but not at the plant where most Liohippelates were aspirated. Larvae of both genera develop in soil containing organic matter such as dung (Nartshuk 2014). The presence of cattle at the lower site, where most Hippelates and Liohippelates were collected, corresponds to a larval habitat of dung-enriched soil. Tachinidae larvae are primarily parasites of insects (Wood 1987). Larvae of the widely distributed tephritid $N$. viridescens develop in flower heads of various Asteraceae (Goeden and Headrick 1992, Foote et al. 1993). Larvae of chrysomelid beetles including Glyptina are phytophagous, and larvae of wasps in Figitidae: Eucoilinae are parasites of fly pupae (Triplehorn and Johnson 2005).

All insects identified were specific to $P$. coryae flowers based on the very high proportion of conspecific pollen carried. Flower constancy was most likely due to the small size of the insects collected and their weak flight capabilities. Beetles and flies also do not transport pollen from flowers to nests, as do bees, and are unlikely to move between flowers 
on distantly separated plants. Weak flight by pollinating insects requires male and female $P$. coryae plants to be near each other. This closeness in proximity was observed at the female plants I sampled, as the furthest male plant was $2 \mathrm{~m}$ away. Proximity of male and female $P$. coryae plants may result from the behavior of seed-dispersing birds. Male and female P. californicum plants likely become clumped from Phainopeplas, Phainopepla nitens (Passeriformes: Ptilogonatidae), eating fruits and defecating seeds on the same host plants (Larson 1996).

Beetles and flies likely transport pollen from male to female $P$. coryae plants on different mouthpart structures. Attalus futilis may have carried pollen on the hairs at the ends of their maxillae (Fig. 1e). Maxillae with dense hairs for pollen collection have been found on other beetles including the European Malachius bipustulatus L. (Barth 1991). Flies likely carried pollen attached to hairs on the labella at the tip of the proboscis, as observed in P. californicum (Fig. 1d, le in Wiesenborn 2016). Relatively high conspecific pollen loads on the Liohippelates may have been due to the structure of their labellae, which were large and supported much longer hairs than the labellae of the other chloropids collected.

Phoradendron coryae was most likely pollinated by the melyrid A. futilis and chloropid flies, especially the Liohippelates. Attalus futilis was the most frequently aspirated insect on female flowers, and individual Liohippelates carried the most conspecific pollen. Total numbers of $P$. coryae pollen were similar on both species. The potential pollination of $P$. coryae by a beetle is unexpected and contradicts Trelease's (1916) hypothesis that Phoradendron is pollinated by flies and small bees. Despite their occurrence in flowers, melyrids are not generally known as effective pollinators (Bernhardt 2000). Musty-smelling Ferraria (Iridaceae) flowers in South Africa are visited by melyrid beetles that carry pollen on their dorsum (Goldblatt et al. 2009). Chloropidae are known pollinators of a few plant species (Larson et al. 2001). The orchid Genoplesium littorale D.L. Jones (Orchidaceae), an Australian species with small flowers, is pollinated exclusively by chloropid flies, primarily females (Bower et al. 2015). Chloropid flies in Liohippelates and Hippelates may not be widespread pollinators of $P$. coryae. The localized abundances of the 2 species at the lower site may have resulted from cattle providing dung-enriched soil for larvae and eye secretions for adults. Cattle grazing may increase populations of some insects (while decreasing populations of others) that potentially pollinate the plant.

Phoradendron californicum and P. coryae appear to be pollinated very differently. One obvious difference is the size of insect visitors. Insects collected from female flowers on $P$. californicum (Wiesenborn 2016) and measured with the reticle varied in length from $2.2 \mathrm{~mm}$ in a parasitic wasp (Pteromalidae: Heteroschema sp.) to $22 \mathrm{~mm}$ in honey bees (Apidae: Apis mellifera). Nearly all (98\%) of the insects identified on $P$. coryae were $<3 \mathrm{~mm}$ in length. Flower size is unlikely to account for this difference, because female flowers on both species are around $1 \mathrm{~mm}$ in diameter. One possible difference between plants is the extent that flowers were open. Female flowers appeared to be open further on P. californicum (Fig. 1c in Wiesenborn 2016) than on P. coryae (Fig. 1b). This was apparent in the field, as a hand lens was required to determine if flowers were open on $P$. coryae but not on $P$. californicum. Flower opening in both species may be influenced by rainfall, which affects plant water content. A second difference in pollination between the 2 plants was the diversity of insects visiting flowers. Female flowers on $P$. californicum were visited by 16 species of insects in 13 genera, 9 families, and 2 orders compared with 9 species and genera, 6 families, and 3 orders in P. coryae. A third difference between plants was the taxa of insects aspirated. Most insects on P. californicum were flies in Tephritidae followed by Calliphoridae and Syrphidae (Wiesenborn 2016). Calliphorids and syrphids were not found on $P$. coryae, and only 3 tephritids (in a genus not found on $P$. californicum) were identified. Conversely, flowers on P. californicum were not visited by Coleoptera or Chloropidae.

Insect visitors to flowers were unique between the 2 Phoradendron species. Insect size, diversity, and taxa are not independent of each other because a size limitation would affect diversity and taxa. Compositions of insects visiting flowers on both species may have been influenced by relative amounts of nectar, plant water content, and pollen. The 
different plant communities and flowering seasons of $P$. californicum and $P$. coryae would also influence the diversity and taxa of available insects. Although Phoradendron flowers are simple and similar, pollination may differ among species more than expected.

\section{ACKNOWLEDGMENTS}

I am grateful to Doug Yanega and Serguei Triapitsyn at the Entomology Research Museum, University of California, Riverside, and Brian Brown at the Los Angeles County Natural History Museum for making their collections available to me. I thank Adriean Mayor for helping me with melyrid taxonomy. I also appreciate the helpful critiques provided by the reviewers.

\section{Literature Cited}

AllRed, K.W., AND R.D. IveY. 2012. Flora neomexicana III: an illustrated identification manual. PDF e-book; [purchased 10 December 2015]. https://www.lulu.com

BARTH, F.G. 1991. Insects and flowers: the biology of a partnership. Princeton University Press, Princeton, NJ.

BERnhaRdT, P. 2000. Convergent evolution and adaptive radiation of beetle-pollinated angiosperms. Plant Systematics and Evolution 222:293-320.

Bower, C., B. Towle, and D. Bickel. 2015. Reproductive success and pollination of the Tuncurry midge orchid (Genoplesium littorale) (Orchidaceae) by chloropid flies. Telopea 18:43-55.

Brown, B.V. 1993. A further chemical alternative to criticalpoint-drying for preparing small (or large) flies. Fly Times 11:10.

Brown, D.E. 1982. Great Basin conifer woodland. Pages 52-57 in D.E. Brown, editor, Biotic communities of the American Southwest - United States and Mexico. Desert Plants 4:1-342.

DAFNI, A. 1992. Pollination ecology: a practical approach. IRL Press at Oxford University Press, Oxford, England, United Kingdom.

Dix, M.E. 1990. Malachius ulkei Horn (Coleoptera: Malachiidae): an egg predator of Paleacrita vernata Peck (Lepidoptera: Geometridae). Journal of the Kansas Entomological Society 63:648-652.

[DRI] Desert Research Institute. 2015. Cooperative climatological data summaries. Western Regional Climate Center, Reno, NV; [accessed 14 December 2015]. www.wrcc.dri.edu/summary/Climsmaz.html

Faegri, K., P.E. Kaland, and K. Krzywinski. 1989. Textbook of pollen analysis. 4th edition. John Wiley \& Sons, New York, NY.

FALL, H.C. 1917. Short studies in the Malachiidae (Coleoptera). Transactions of the American Entomological Society 43:67-88.

Foote, R.H., F.L. Blanc, and A.L. Norrbom. 1993. Handbook of the fruit flies (Diptera: Tephritidae) of America north of Mexico. Comstock Publishing Associates, Ithaca, NY
Goeden, R.D., and D.H. Headrick. 1992. Life history and descriptions of immature stages of Neaspilota viridescens Quisenberry (Diptera: Tephritidae) on native Asteraceae in southern California. Proceedings of the Entomological Society of Washington 94:59-77.

Goldblatt, P., P. Bernhardt, and J.C. Manning. 2009. Adaptive radiation of the putrid perianth: Ferraria (Iridaceae: Irideae) and its unusual pollinators. Plant Systematics and Evolution 278:53-65.

Hadley, A. 2013. CombineZP; [accessed 14 December 2015]. http://www.hadleyweb.pwp.blueyonder.co.uk

Hawksworth, F.G., and D. Wiens. 2002. Viscaceae, mistletoe family. Pages 513-514 in B.G. Baldwin et al., editors, The Jepson desert manual. University of California Press, Berkeley, CA.

Kearney, T.H., and R.H. Peebles. 1951. Arizona flora. University of California Press, Berkeley, CA

KING, P.S. 1985. Natural history of Collops georgianus (Coleoptera: Melyridae). Annals of the Entomological Society of America 78:131-136.

KuijT, J. 1969. The biology of parasitic flowering plants. University of California Press, Berkeley, CA.

Kuijt, J. 2003. Monograph of Phoradendron (Viscaceae). Systematic Botany Monographs 66:1-643.

Larson, B.M.H., P.G. Kevan, and D.W. Inouye. 2001. Flies and flowers: taxonomic diversity of anthophiles and pollinators. Canadian Entomologist 133:439-465.

LaRson, D.L. 1996. Seed dispersal by specialist versus generalist foragers: the plant's perspective. Oikos $76: 113-120$

Marshall, M.Y. 1953. Studies in the Malachiidae - IV. American Midland Naturalist 49:825-831.

MayoR, A.J. 2002. Melyridae Leach 1815. Pages 281-304 in R.H. Arnett, Jr., et al., editors, American beetles. Volume 2. Polyphaga: Scarabaeoidea through Curculionoidea. CRC Press, Boca Raton, FL.

MCAlpine, J.F. 1981. Key to families - adults. Pages 89-124 in J.F. McAlpine et al., coordinators, Manual of Nearctic Diptera. Volume 1. Agriculture Canada Monograph No. 27, Canadian Government Publishing Centre, Quebec, Canada.

[MCFCD] Mohave County Flood Control District. 2015. Rainfall. Mohave County, Kingman, AZ; [accessed 14 December 2015]. http://weather.co .mohave.az.us/rainfallmapfs60m.html

MunZ, P.A. 1974. A flora of southern California. University of California Press, Berkeley, CA.

NartshuK, E.P. 2014. Grass-fly larvae (Diptera: Chloropidae): diversity, habitats, and feeding specializations. Entomological Review 94:514-525.

Neter, J., M.H. Kutner, C.J. Nachtsheim, and W. Wasserman. 1996. Applied linear statistical models. 4th edition. WCD McGraw-Hill, Boston, MA.

NixON, K.C. 1997. Fagaceae Dumortier: beech family. Pages 436-506 in Flora of North America Editorial Committee, Flora of North America north of Mexico. Volume 3. Magnoliophyta: Magnoliidae and Hamamelidae. Oxford University Press, New York, NY.

Pase, C.P., and D.E. Brown. 1982. Interior chaparral. Pages 95-99 in D.E. Brown, editor, Biotic communities of the American Southwest - United States and Mexico. Desert Plants 4:1-342.

Reinhard, H.J. 1942. New North American Tachinidae belonging to the genera Microchaetina and Hypenomyia with key to the known species (Diptera). Canadian Entomologist 74:88-91. 
Riley, E.G., S.M. Clark, R.W. Flowers, and A.J. Gilbert. 2002. Chrysomelidae Latreille 1802. Pages 617-691 in R.H. Arnett, Jr., et al., editors, American beetles. Volume 2. Polyphaga: Scarabaeoidea through Curculionoidea. CRC Press, Boca Raton, FL.

Sabrosky, C.W. 1987. Chloropidae. Pages 1049-1067 in J.F. McAlpine, editor, Manual of Nearctic Diptera. Volume 2. Agriculture Canada Monograph No. 28, Canadian Government Publishing Centre, Quebec, Canada.

Stork, N.E., AND P.M. Hammond. 2013. Species richness and temporal partitioning in the beetle fauna of oak trees (Quercus robur L.) in Richmond Park, UK. Insect Conservation and Diversity 6:67-81.

Tanner, V.M., and W.W. Tanner. 1974. Additional records of Coleoptera collected at the Nevada Test Site, Mercury, Nevada. Great Basin Naturalist 34: 218-220.

Trelease, W. 1916. The genus Phoradendron: a monographic revision. University of Illinois, Urbana, IL.

Triplehorn, C.A., AND N.F. Johnson. 2005. Borror and DeLong's introduction to the study of insects. 7th edition. Thomson Brooks/Cole, Belmont, CA.

WALKER, J.K. 1957. A biological study of Collops balteatus Lec. and Collops vittatus (Say). Journal of Economic Entomology 50:395-399.
Wheeler, T.A. 2010. Chloropidae (fruit flies, grass flies, eye gnats). Pages 1137-1153 in B.V. Brown et al., editors, Manual of Central American Diptera. Volume 2. NRC Research Press, Ottawa, Canada.

WhitTaker, P.L. 1984. The insect fauna of mistletoe (Phoradendron tomentosum, Loranthaceae) in southern Texas. Southwestern Naturalist 29:435-444.

WiEns, D. 1964. Revision of the acataphyllous species of Phoradendron. Brittonia 16:11-54.

Wiesenborn, W.D. 2016. Conspecific pollen loads on insects visiting female flowers on parasitic Phoradendron californicum (Viscaceae). Western North American Naturalist 76:113-121.

Wilson, E.A., P.J. Sullivan, and J.L. Dickinson. 2014. Spatial distribution of oak mistletoe as it relates to habits of oak woodland frugivores. PLOS ONE 9: e111947.

Wood, D.M. 1987. Tachinidae. Pages 1193-1269 in J.F. McAlpine, editor, Manual of Nearctic Diptera. Volume 2. Agriculture Canada Monograph No. 28, Canadian Government Publishing Centre, Quebec, Canada.

Received 16 December 2015 Accepted 6 May 2016 